A critical evaluation of the contribution of trust to effective Technology Enhanced Learning in the workplace: a literature review

Heather Short

\title{
Practitioner notes
}

What is already known about this topic:-

- trust is important in both business and educational contexts;

- trust is important in the virtual environment;

- lack of face-to-face contact reduces trust;

- little research has been undertaken into how the formation and development of trust between trainer and students and amongst students is influenced by a virtual environment.

What this paper adds:-

- how trust affects learning;

- the role of trust in virtual working;

- issues concerning trust during TEL;

- the possibility that virtual meetings could increase trust during TEL.

Implications for practice and / or policy:-

- If virtual meetings before and during TEL can establish and build trust between trainer and students and amongst students, this could have a significant effect on the take-up and effectiveness of TEL

- Such an increase in TEL usage and efficacy could be significant not just for $\mathrm{HR}$, specifically learning, but for business in general and for the economy as a whole.

\section{Abstract}

This paper offers a critical review of the literature which explores the building and development of trust in workplace learning, particularly in a virtual context and its implications for Technology Enhanced Learning (TEL) in business.

Trust is increasingly recognised as important in both business and education and is the focus of increasing attention in relation to the virtual environment. TEL offers a range of potential benefits, but adoption levels remain low. However, there are indications that trust may be a significant factor in both low workplace participation in TEL and its effectiveness as a learning medium. Although savings in both money and time are the main perceived advantages of TEL, this review highlights the positive role of face-to-face contact in increasing TEL take-up and effectiveness, even though this diminishes cost-savings.

This paper highlights the scant level of research into TEL, particularly in work situations, and the extent to which trust has been overlooked in this context. In the light of this gap in knowledge, further investigations are suggested to contribute to understanding the issues affecting TEL in the workplace. 


\section{Introduction}

This paper highlights the importance of trust (Zand, 1972; Mayer, Davis, and Schoorman, 1995; Blomqvist, 2002) in both business (Drucker, 1999; Vice and Carnes, 2001, Kouzes and Posner, 2012; Newcombe, 2012) and learning contexts (Mason and Rennie, 2008; Grover and Stewart, 2010). Although Handy (1995), Gignac (2005) and Rintala (2008) agree on the importance of trust in a virtual environment, little research has been undertaken into how the formation and development of trust is influenced by this setting (Wainfan and Davis, 2004; Henttonen and Blomqvist, 2005).

Key features of the literature across the social sciences indicate that lack of face-toface contact reduces trust (Handy, 1995; Kostner, 2001; Gignac, 2005; Rintala, 2008; Brown and Lightfoot, 2009). Although on-line learning environments preclude faceto-face contact, the development of online communities indicates that opportunities for participants to meet as if face-to-face increases full and open participation (Miller, Fairhurst and Chubb, 2010). In the field of education and training, whether students have met the trainer and / or each other prior to virtual learning seems to greatly influence the level of trust between them (Kostner, 2001; Wainfan and Davis, 2004; Miller et al., 2010). Furthermore, the suggestion that such "meeting" can be virtual (Kostner, 2001; Walther, Slovacek and Tidwell, 2001; Wainfan and Davis, 2004) merits more investigation.

In the current economic environment the need for cost-effective training methods is stronger than ever (Johnson, Scholes and Whittington, 2008; Business Matters Magazine, 2012; Mullins, 2013) and TEL could be seen as an attractive option (Shaw, 2012), especially as technology's availability and affordability are increasing (Loos, Mante-Meijer and Haddon, 2008; Serenko and Turel, 2010; ONS, 2012). However, TEL's take-up is surprising low (Mote, 2012), although Head (2012) observes that how TEL is perceived could be very significant in its rate of adoption.

Therefore, this paper seeks to answer the following questions:-

- What is trust and how does it affect learning?

- What role does trust play in virtual working? and

- What are the issues concerning trust in TEL?

The paper looks at each of these questions drawing on literature from both the practitioner and academic arenas, examining research which is relevant to each specific question and to the relationships between the questions. The paper contributes a detailed examination of the barriers to the development of trust in TEL and factors which encourage it in TEL situations. After summarising the key issues arising from the literature review, the limitations of the paper and suggested areas for further research are outlined.

\section{What is trust and how does it affect learning?}

Trust is a complex and multi-faceted concept (Lyon, Möllering and Saunders, 2012) with over seventy definitions (Seppanen, Blomqvist and Sundqvist, 2007), although academics widely use Zand's definition (1997): 
"a willingness to increase your vulnerability to another person whose behaviour you cannot control, in a situation in which your potential benefit is much less than your potential loss if the other person abuses your vulnerability" (p. 91).

Furthermore, McEvily and Tortoriello's review (2011) of 96 case-studies identifies forty-seven different methodologies to measure trust.

Trust is crucial in a learning situation and ideas and information are unlikely to be shared without it (Mason and Rennie, 2008; Grover and Stewart, 2010). Drawing on twenty years' teaching experience, Ossiansson (2010) suggests that teachers can earn students' trust and commitment by giving away some control and building a longterm bond with their students, contending that an asymmetrical relationship is unlikely to achieve this result. Birchall and Giambona (2007) assert that the need for trust grows as students move through the phases of learning, but that it is the process of moving through these stages which allows both relationships and trust to grow. Like Ossiansson (2010) and Volchok (2010), they believe that trust requires a studentcentric environment, rather than a trainer-centric one, as the latter, with its assumption that students need constant supervision, does not encourage students to feel involved in the process.

Having established the importance of trust in the learning environment and examined some ways in which it can be formed and grown, this paper will continue by examining it in virtual situations.

What role does trust play in virtual working?

Trust has long been recognised as important in business situations (Zand, 1972; Butler, 1991; Stoner and Hartman, 1993; Kouzes and Posner, 2012). Järvenpää and Eloranta (2001) show that the development of networked communication technologies in the 1990's led to distance-working which consequently reduced face-to-face communication and so ultimately resulted in virtual organizations. Handy (1995) asserts that virtual working changes the nature of group work which leads to the requirement for new forms of belonging. Therefore, he advises that workers should meet face-to-face occasionally to achieve the group's objectives efficiently and effectively. He affirms that managing people in different locations requires trust, stating that "virtuality requires trust to make it work: technology on its own is not enough" (1995, p44) and consequently he suggests that this needs a big change in organizational thinking. He further comments that trust cannot be taken for granted in such circumstances and therefore its role should be both acknowledged and managed. This aligns with the findings of Kostner (2001), who quotes (p. 62) Jimmy Treybig, former CEO of Tandem Computers: "Creating trust is hard to do with e-mail. We communicated heavily through technology. But you have to have the personal part, too." The importance of building trust online is reiterated by Stoner and Hartman (1993) and Gignac (2005), the latter seeing it as the "virtual challenge" (p61), which Henttonen and Blomqvist (2005) agree with. Gignac (2005) believes that solely focusing on technology will not bring success. She warns that lack of trust affects results, stressing that formation and growth of such trust is particularly difficult in virtual teams. Her reasons include the organization's culture and leadership style as well as the extent and nature of employee learning and development. Furumo, de Pillis and Buxton (2012) state that leadership style in virtual teams influences the 
initial formation of trust and the subsequent level of participation by team-members. They distinguish between supportive leaders whose participative style engenders more trust and "Commander leaders" (p. 125) whose authoritarian approach is likely to impede the growth of trust, therefore leading to lower participation by team-members. Preece, Rogers and Sharp (2011) observe that designers of interactive systems, which form the basis of both virtual working and TEL, must consider social factors, not just technology. They espouse that any form of working virtually needs both communication skills and collaborative activity and that the social mechanisms of these, that is conversation, awareness and coordination, provide a framework to develop such skills for virtual working. This builds on Lewicki and Bunker's (2008) view that the development of trust is closely connected with the development of relationships. Furthermore both Storck and Sproull (1995) and Henttonen and Blomqvist (2005) note that the identities of participants in virtual teams may be more ambiguous due to their being separated by time and space.

Kostner's (2001) research demonstrates how electronic communications make contact between individuals easier and faster and also allow the establishment of relationships, although she agrees with Handy (1995) that some face-to-face contact is needed to progress relationships, particularly in projects' initiation phases. Brown and Lightfoot (2009) cite people who are reluctant to undertake any business virtually with people they have not already met.

This has shown that virtual working has altered the nature of the workplace and increased the need for trust. It illustrates that effective working in such an environment is dependent on factors such as leadership style and communication, with some face-to-face contact helping to build collaborative relationships. Next the findings from this and the previous section will be developed by examining learning in a virtual setting.

\section{What are the issues concerning trust in TEL?}

In a learning context, McCroskey and Teven (1999) contend that competence, evidence of caring and trust are all necessary for an instructor to be perceived as credible. Similarly, although Grover and Stewart (2010) highlight how electronic learning can offer students opportunities for social interaction, they recognise that concerns exist about confidentiality and trust in the virtual environment. BoschSijtsema (2007) notes that expectations are important in the formation of trust and must be explicit in virtual learning situations. Hinds and Bailey (2003) agree that the virtual environment prevents students from establishing common ground and expectations and thus limits the opportunities for building trust.

Several issues appear to influence trust in TEL and some of these are examined below, including cues, teams, time, interaction, information exchange and participation, together with a brief comparison of physical and virtual environments in this context.

Cues, teams and time

Birchall and Giambona (2007) attribute limitations to the growth of trust to the lack of cues in virtual situations. Furthermore Järvenpää and Leidner's study (1999) of communication and trust in global teams shows that technology, through its lack of physical cues, can adversely affect the interpersonal aspects of team-working, such as 
trust, warmth and attentiveness. Similarly Donath (1999), Kimble, Li and Barlow (2000), Wainfan and Davis (2004), Gignac (2005), Henttonen and Blomqvist (2005) and Volchok (2010) all observe that difficulties in building trust online may be due to the absence of cues which would be present in physical situations, with Volchok (2010) also stressing that the expectations of individual team-members are difficult to ascertain in the virtual environment. However, Volchok (2010) maintains that these problems can be overcome in learning situations by using teams wisely, which he has done since 2002. He wants his students to concentrate on what he is teaching, not on any short-comings of the virtual environment. Consequently he allows time for social interaction amongst the team and encourages his students to participate. He believes that to receive trust, it is necessary to give trust and that therefore a trainer should be accessible and responsive, keep confidences, communicate openly and frequently and be honest, consistent and predictable, doing what he / she says he / she will do. Volchok sets the tone for each virtual learning team as it is set up, aiming to encourage future interaction and establishing strong business ethics from the start.

Contrastingly, Walther (1997) and Kostner (2001) assert that virtual teams can have more social discussion, depth and intimacy than face-to-face ones, concluding, therefore, that the lack of social cues in virtual communication does not necessarily preclude the building of relationships and the establishment of identities, although it may take longer (Henttonen and Blomqvist, 2005). Uber Grosse (2010) agrees, stressing the importance of team-members becoming acquainted as soon as possible and referencing Nokia which prefers its virtual teams to have several members who have worked together previously. This is because Nokia has found that prior knowledge, existing relationships and trust between team-members are all important factors in an effective team and so seek to capitalise on this. Building on Child's assertion (2001) that virtual teams, where there is much uncertainty and little knowledge of each other, are dependent upon mutual trust for their success, new team members are encouraged to develop personal relationships with each other online. This aligns with Meyerson, Weick and Kramer's view (1996) that, in virtual teams, interaction increases trust and decreases ambiguity and uncertainty. Volchok (2010) observes that the most successful teams tackle problems together and share responsibility not only for any problems arising, but also for successes achieved.

\section{Interaction}

Kostner (2001) and Fairhurst and Miller (2011) contend that productivity / learning can be improved through increased social interaction, such as encouraging students who are undergoing regular virtual learning as a group to email each other, thus forming a virtual team. Furthermore Arbaugh, (2000), Frymier and Houser (2000) and Stocks and Freddolina (2000) all show that interaction increases learning, with Frymier and Houser finding that it also positively influences students' motivation. However, Stephens and Mottet (2008) claim that TEL's nature allows little time or opportunity for relationships to develop between trainer and students. Stephens and Mottet's case study (2008) specifically examines interaction both between trainer and students and between students themselves in web-conferences which are set up for training purposes. Their initial hypotheses are that students learn more when trainers intentionally make their lessons interactive and that in such situations students are more satisfied with the training. Neither of these is supported. However, their other hypothesis is that trainers who facilitate interaction during their training are perceived by their students as being more credible and this is supported, with trainees also 
seeing such trainers as being caring. Similarly both Myers and Martin (2006) and McCroskey and Teven (1999) find that trainers' credibility is enhanced by the degree to which they encourage interaction with, and amongst, their students.

Information exchange and participation

Although many definitions of interaction exist, they share two important features, namely information exchange and participation (Steuer, 1992; Ha and James, 1998). Accordingly Wainfan and Davis (2004) claim that virtual learning concentrates on information exchange to the detriment of participation with technology being more appropriate for task goals than relational ones. Furthermore, Daft and Lengel's research (1986) finds that virtual communication discourages social interaction, but is more successful in task-oriented contexts. Stephens and Mottet (2008) comment that, although favouring information exchange over participation, technology offers trainer-controlled tools which give opportunities for interaction. Castells (2001) concludes that electronic media allow online environments to be tailored to individual tastes and needs, leading to "me-centred networks" (p. 128), which Knowles (1990) claims adult learners favour.

Physical versus virtual environments

The literature reviewed indicates that, although similar problems between students and trainers may occur whether they are in physical or virtual environments, these areas of concern are likely to be exacerbated in non-face-to-face situations (Moore, 1993). TEL may result in feelings of isolation through the lack of "water cooler" moments (Kostner, 2001, p. 16; Fairhurst and Miller, 2011, p. 52) which are inherent in such circumstances, and there are indications that this could result in lack of trust between student and trainer and amongst students.

\section{Conclusions}

Having investigated the three questions

- What is trust and how does it affect learning?

- What role does trust play in virtual working? and

- What are the issues concerning trust in TEL?

this review illuminates the importance of trust, its effect upon learning, its role in virtual situations and issues concerning it which arise from TEL. Table 1 summarises the literature which has been reviewed, showing the issues and factors arising in the contexts of the workplace, virtual working, virtual teams and TEL.

\begin{tabular}{|c|c|c|c|}
\hline Context & Issue & Factor & References \\
\hline Workplace & $\begin{array}{l}\text { Trust closely } \\
\text { associated } \\
\text { with } \\
\text { relationship } \\
\text { building }\end{array}$ & & \begin{tabular}{|l} 
Lewicki and Bunker's (2008) \\
\end{tabular} \\
\hline Virtual working & $\begin{array}{l}\text { Importance } \\
\text { of Trust }\end{array}$ & & $\begin{array}{l}\text { Gignac (2005); Henttonen and } \\
\text { Blomqvist (2005); Kostner (2001); } \\
\text { Handy (1995); Stoner and Hartman } \\
(1993)\end{array}$ \\
\hline Virtual working & Trust & (Physical) cues & Volchok (2010); Birchall and \\
\hline
\end{tabular}




\begin{tabular}{|c|c|c|c|}
\hline & & & $\begin{array}{l}\text { Giambona (2007); Gignac (2005), } \\
\text { Henttonen and Blomqvist (2005); } \\
\text { Wainfan and Davis (2004); Kimble, } \\
\text { Li and Barlow (2000); Donath } \\
\text { (1999) }\end{array}$ \\
\hline Virtual teams & Trust & (Physical) cues & Järvenpää and Leidner (1999) \\
\hline Virtual teams & $\begin{array}{l}\text { Trust } \\
\text { (leading to } \\
\text { participation) }\end{array}$ & Leadership style & $\begin{array}{l}\text { Furumo, de Pillis and Buxton } \\
\text { (2012) }\end{array}$ \\
\hline Virtual teams & $\begin{array}{l}\text { Relationship- } \\
\text { building / } \\
\text { identity } \\
\text { establishment }\end{array}$ & $\begin{array}{l}\text { Social } \\
\text { discussion, depth } \\
\text { and intimacy }\end{array}$ & Walther (1997); Kostner (2001) \\
\hline Virtual teams & $\begin{array}{l}\text { Relationship- } \\
\text { building / } \\
\text { identity } \\
\text { establishment }\end{array}$ & Time; space & $\begin{array}{l}\text { Henttonen and Blomqvist, 2005; } \\
\text { Storck and Sproull (1995) }\end{array}$ \\
\hline $\begin{array}{l}\text { Virtual } \\
\text { working, TEL }\end{array}$ & $\begin{array}{l}\text { Relationship } \\
\text { building }\end{array}$ & $\begin{array}{l}\text { Social } \\
\text { interaction }\end{array}$ & Preece, Rogers and Sharp (2011) \\
\hline $\begin{array}{l}\text { Virtual } \\
\text { working, virtual } \\
\text { teams, TEL }\end{array}$ & $\begin{array}{l}\text { Productivity / } \\
\text { increased } \\
\text { learning }\end{array}$ & $\begin{array}{l}\text { Social } \\
\text { interaction }\end{array}$ & $\begin{array}{l}\text { Fairhurst and Miller (2011); } \\
\text { Kostner (2001); Arbaugh, (2000), } \\
\text { Frymier and Houser (2000); Stocks } \\
\text { and Freddolina (2000) }\end{array}$ \\
\hline TEL & Trust & Expectations & $\begin{array}{l}\text { Volchok (2010); Bosch-Sijtsema } \\
\text { (2007); Hinds and Bailey (2003) }\end{array}$ \\
\hline TEL & Trust & $\begin{array}{l}\text { Establishing } \\
\text { common ground }\end{array}$ & Hinds and Bailey (2003) \\
\hline TEL & Trust & $\begin{array}{l}\text { Feelings of } \\
\text { isolation }\end{array}$ & $\begin{array}{l}\text { Fairhurst and Miller (2011); } \\
\text { Kostner (2001) }\end{array}$ \\
\hline TEL & $\begin{array}{l}\text { Relationship- } \\
\text { building }\end{array}$ & Time & Stephens and Mottet (2008) \\
\hline TEL & $\begin{array}{l}\text { Relationship } \\
\text { building } \\
\text { (trainer } \\
\text { credibility) }\end{array}$ & $\begin{array}{l}\text { Social } \\
\text { interaction }\end{array}$ & $\begin{array}{l}\text { Stephens and Mottet (2008); Myers } \\
\text { and Martin (2006); McCroskey and } \\
\text { Teven (1999) }\end{array}$ \\
\hline TEL & Motivation & $\begin{array}{l}\text { Social } \\
\text { interaction }\end{array}$ & Frymier and Houser (2000) \\
\hline
\end{tabular}

Table 1 : To show Issues and Factors highlighted by the literature reviewed in the contexts of the workplace, virtual working, virtual teams and TEL

The contribution of this review, in light of these questions, is to show that there is evidence that measures can be taken to encourage the establishment and growth of trust in TEL, as summarised below.

The first key issue emerging from this literature review is that trust is widely seen as an important part of relationships in the workplace, particularly in learning situations. Secondly, there is widespread agreement that trust is more difficult to establish and to nurture in the virtual world than it would be in face-to-face circumstances and, although some writers contend that trust will evolve naturally, there is agreement that 
building trust takes longer if those concerned are only communicating electronically. Thirdly, the main barriers to the development of trust in virtual environments appear to be lack of time, lack of physical cues, technological problems, feelings of isolation and ambiguity regarding the identity of one's co-workers. Additionally evidence suggests that people who have met previously seem to work together virtually more effectively than those who have not. There are suggestions that such "meeting" can itself be virtual (Walther et al., 2001), but little research exists to support this, although further investigation in this area could benefit businesses of all sizes.

A limitation of this review is that although many searches have been undertaken to find pertinent material, it would, of course, be impossible to find everything relevant and so significant works may have been missed. Additionally, as can be seen throughout the review, although items have been found which relate separately to trust, learning and the virtual environment, little has been found which combines all these areas. Finally TEL, through its very nature, is advancing at an increasingly fast rate and so more current material is likely to be available by the time this review is read.

Perhaps the greatest limitation of this review is that the questions posed have not been fully answered as no research has been found specifically regarding trust and TEL in the workplace which suggests that primary research should be undertaken in this area. As indicated above, the possibility of virtual, rather than physical, meetings being used to develop social relationships in TEL and thus increase the effectiveness of such learning, merits particular investigation.

\section{Acknowledgements}

The author would like to acknowledge the assistance of Dr Sarah Gilmore and Dr Valerie Anderson in this study. 
References

Arbaugh, J. B. (2000). How classroom environment and student engagement affect learning in Internet-based MBA courses Business Communication Quarterly, Vol. 63 Number 4, pp. 9-26

Birchall D. \& Giambona G. (2007). SME manager development in virtual learning communities and the role of trust: A conceptual study Human Resource Development International Vol. 10 Issue 2, pp. 187-202

Blomqvist K. (2002). Partnering in the dynamic environment: the role of trust in asymmetric technology partnership formation Acta Universitatis: Lappeenrantaensis 122, Lappeenranta

Bosch-Sijtsema, P. (2007). The Impact of Individual expectations and expectation Conflicts on Virtual Teams Group and Organization Management Vol. 32, Number 3 pp. $358-388$

Brown, S. D. \& Lightfoot, G. (2009). Presence, Absence and accountability: Email and the Mediation of organizational memory in Woolgar, S. (Ed.) Virtual Society? : Technology, Cyberbole, Reality ( $2^{\text {nd }}$ edn.) Oxford: Oxford University Press

Business Matters Magazine (2012). Employers find cost effective training alternatives for staff development [www.bmmagazine] URL

http://www.bmmagazine.co.uk/opinion/9664/employers-find-cost-effective-trainingalternatives-for-staff-development/

Butler, J. K. (1991). Toward understanding and measuring conditions of trust; Evolution of a conditions of trust inventory Journal of Management Vol. 17 Issue 3 pp. 643-663

Castells, M. (2001). The Internet Galaxy: Reflections on the Internet, Business and Society Oxford: Oxford University Press

Child, J. (2001). Trust - the fundamental bond in global collaboration Organizational Dynamics Vol. 29 Issue 4 pp. 274-288

Daft, R. L. \& Lengel, R.H. (1986). Organizational information requirements, media richness, and structural design Management Science Vol. 32, pp. 554-571

Donath, J.S. (1999). Identity and deception in the virtual community in Smith M.A. \& Kollock, P. (Eds.) Communities in cyberspace London: Routledge

Drucker P. F. (1999). Management Challenges for the $21^{\text {st }}$ Century New York: Harper Business

Fairhurst, P. \& Miller, L. (2011). Creating social networks for L\&D, The Training Journal July 2011 pp. 50-54

Frymier, A. B. \& Houser, M. L. (2000). The teacher-student relationship as an interpersonal relationship, Communication Education Vol. 49 Number 3, pp. 207-219 
Furumo, K. de Pillis, E. \& Buxton, M. (2012). The impact of leadership on participation and trust in virtual teams SIGMIS-CPR' 12 (Proceedings of $50^{\text {th }}$ Annual Conference on Computers and People Research, ACM, New York (p. 123-126) retrieved online $2 / 2 / 13$ at http://dl.acm.org/citation.cfm?id=2214091.2214125\&coll=DL\&dl=GUIDE\&CFID=1 86043574\&CFTOKEN=12087980

Gignac, F. (2005). Building Successful Virtual Teams, Norwood, USA, Artech House Incorporated

Grover, A. \& Stewart, D.W. (2010). Defining interactive social media in an educational context in Wankel, C. (Ed.), Cutting-Edge Social Media Approaches to Business Education: Teaching with LinkedIn, Facebook, Twitter, Second Life, and Blogs Greenwich, Connecticut, USA: Information Age Publishing pp. 7-38

Ha, L. \& James, E. L. (1998). Interactivity re-examined: A baseline analysis of early business Websites Journal of Broadcasting \& Electronic Media, Vol. 42 Number 4, pp. $457-474$

Handy, C. (1995). Trust and the Virtual Organization Harvard Business Review Vol. 73 Number 3, pp. 40-50

Head, S.K. (2012). MOOCs - The revolution has begun, says Moody's University World News 23 September 2012, Issue No 240

Henttonen, K. \& Blomqvist, K. (2005). Managing distance in a global virtual team: the evolution of trust through technology-mediated relational communication.

Strategic Change Vol. 14, pp. 107-119

Hinds, P. \& Bailey, D. (2003). Out of sight, out of sync: understanding conflict in distributed teams Organization Science Vol. 14 Issue 6, pp. 615-632

Järvenpää, E. \& Eloranta, E. (2001). Information and Communication Technologies and Quality of Working Life: Implications for Competencies and Well-Being, in Bradley, G. (Ed.), Humans on the Net: Information and Communication Technology (ICT), Work Organization and Human Beings, Stockholm: Prevent

Järvenpää, S.L. \& Leidner, D. (1999). Communication and Trust in Global Virtual Teams Organization Science Vol. 10 Number 6, pp. 791-815

Johnson, G., Scholes, K. \& Whittington, R. (2008). Exploring corporate strategy (8 ${ }^{\text {th }}$ Edition) Financial Times Prentice Hall, Harlow, UK

Kimble, C. Li, F. \& Barlow, A. (2000). Effective virtual teams through communities of practice Paper 2000/9 University of Strathclyde Business School

Knowles, M. (1990). The adult-learner: A neglected species Houston, Texas, Gulf Publishing Company 
Kostner, J. (2001). Bionic e-Teamwork : How to Build Collaborative Virtual Teams at Hyperspeed, Chicago, USA, Dearborn Trade

Kouzes, J. M. \& Posner, B. Z. (2012). The Leadership Challenge: How to make extraordinary things happen in organizations $\left(5^{\text {th }}\right.$ edn.) Somerset, New Jersey: Wiley

Lewicki, R.J. \& Bunker, B.B. (2008). Developing and maintaining trust in work relationships in Landmark Papers on Trust, Vol. 2, Bachman R. \& Zaheer A. (Eds.) Elgar: Cheltenham pp. 388-413

Loos, E.E. (Ed.) Mante-Meijer, E. (Ed.) \& Haddon, L. (Ed.) (2008). The Social Dynamics of Information and Communication Technology, Aldershot, Ashgate Publishing Group

Lyon, F. (Ed.) Möllering, G. (Ed.) \& Saunders, M.N.K. (Ed.) (2012). Handbook of Research Methods on Trust Cheltenham, Glos, GBR: Edward Elgar Publishing

Mason, R. \& Rennie, F. (2008). E-learning and social networking handbook: resources for higher education, London: Routledge

Mayer, R. C., Davis, J. H. \& Schoorman, F. D. (1995). An integrative model of organizational trust Academy of Management Review, Vol. 20, Number 3, pp. 709734

McCroskey, J. C., \& Teven, J. J. (1999). Goodwill: A re-examination of the construct and its measurement Communication Monographs Vol. 66 Number 1, pp. 90-103

McEvily, B. \& Tortoriello, M. (2011). Measuring trust in organizational research: review and recommendations Journal of Trust Research Vol. 1, Number 1, pp. 23- 63

Meyerson, D., Weick, K. E., \& Kramer, R. M. (1996). Swift trust and temporary groups in: R. M. Kramer and T. R. Tyler (Eds.) Trust in organizations: Frontiers of theory and research (Thousand Oaks, California: Sage) pp. 166-195

Miller, L., Fairhurst, R. \& Chubb, C. (2010). Market Research for Online Communities in the NHS: A report to the NHS Institute for innovation and improvement London, NHS Institute for Innovation and Improvement

Moore, M. G. (1993). Theory of transactional distance, in: D. Keegan (Ed.)

Theoretical principles of distance education (New York, Routledge) pp. 22-38.

Mote, C. (2012). Harness the corporate digital footprint HR Magazine, $19^{\text {th }}$ October 2012 retrieved online on 2/11/12 at www.hrmagazine.co.uk

Mullins, L .J. (2013). Management and Organisational Behaviour (10 ${ }^{\text {th }}$ Edn.) Harlow, England: Pearson Education Ltd.

Myers, S. A., \& Martin, M. M. (2006). Understanding the source: Teacher credibility and aggressive communication traits in: T. P. Mottet, V. P. Richmond and J. C. 
McCroskey (Eds.), Handbook of instructional communication: Rhetorical and relational perspectives (Boston: Allyn and Bacon) pp. 67-88

Newcombe, T. (2012). Apprenticeships increase, but there is a drop overall in adult learning in workplace, says BIS HR Magazine 12 October 2012 retrieved online 2/11/12 at www.hrmagazine.co.uk

ONS (Office for National Statistics) (2012). E-commerce and ICT activity, 2006-2011 ONS Online retrieved online 22/8/13 at http://www.ons.gov.uk/ons/search/index.html?newquery=technology+availability

Ossiansson, E. (2010). Facebook 'friendship' as educational practice in Wankel, C. (Ed.), Cutting-Edge Social Media Approaches to Business Education: Teaching with LinkedIn, Facebook, Twitter, Second Life, and Blogs Greenwich, Connecticut, USA: Information Age Publishing pp.117-140

Preece, J., Rogers, Y. \& Sharp, H. (2011). Interaction Design: Beyond Humancomputer interaction $3^{\text {rd }}$ edn. John Wiley: Chichester

Rintala, N. (2008). The impact of ICT implementation on social interaction in work communities in Loos, E.E. Mante-Meijer, E. \& Haddon, L. (Eds.) The Social Dynamics of Information and Communication Technology, Aldershot, Ashgate Publishing Group pp. 133-152

Seppanen, R., Blomqvist, K. \& Sundqvist, S. (2007). Measuring inter-organisational trust: a critical review of the empirical research in 1990-2003 Industrial Marketing Management Vol. 36, Number 2, pp. 249-265

Serenko, A. \& Turel, O. (2010). Rigor and Relevance: The Application of the Critical Incident Technique to Investigate Email Usage Journal of Organizational Computing and Electronic Commerce Vol. 20, Issue 2, pp. 182-207

Shaw, A. (2012). New technologies are key to bringing about change and agility HR Magazine $26^{\text {th }}$ July 2012 retrieved online on 2/11/12 at www.hrmagazine.co.uk

Stephens, K.K. \& Mottet, T.P. (2008). Interactivity in a Web Conference Training Context: Effects on Trainers and Trainees, Communication Education, Vol. 57, Number 1, pp. 88-104

Steuer, J. (1992). Defining virtual reality: Dimensions determining telepresence Journal of Communication, Vol. 42 Number 4, pp. 73-93

Stocks, J. T. \& Freddolino, P. P. (2000). Enhancing computer-mediated teaching through interactivity: The second iteration of a World Wide Web-based graduate social work course Research on Social Work Practice, Vol. 10 Number 4, pp. 505-519

Stoner, C.R. \& Hartman, R.I. (1993). Team building: answering the tough questions Business Horizons Vol. 36 Number 5 pp. 70-78 
Storck, J. \& Sproull, L. (1995). Through a glass darkly: What do people learn in video conference? Human Communication Research Vol. 22 Number 2 pp. 197-219

Uber Grosse, C. (2010). Global Corporate Virtual Teams in Ubell, R. (Ed.) Virtual Teamwork: Mastering the Art and Practice of Online Learning and Corporate Collaboration Hoboken, NJ, USA: Wiley pp. 193-211

Vice, J. P. \& Carnes, L.W. (2001). Developing Communication and Professional Skills through Analytical Reports Business Communication Quarterly Vol. 64 Number 1, pp. 84-98

Volchok, E. (2010). Building Virtual Teams in Ubell, R. (Ed.) Virtual Teamwork : Mastering the Art and Practice of Online Learning and Corporate Collaboration Hoboken, NJ, USA: Wiley pp. 3-15

Wainfan, L. \& Davis, P. (2004). Challenges in Virtual Collaboration : Videoconferencing, and Audioconferencing, and Computer-Mediated Communications Santa Monica, USA, RAND Corporation

Walther, J.B. (1997). Group and interpersonal effects in international computermediated collaboration Human Communication Research Vol. 23 Number 3, pp. 342369

Walther, J. B. Slovacek, C. \& Tidwell, L.C. (2001). Is a Picture Worth a Thousand Words? Photographic Images in Long Term and Short Term Virtual Teams, Communication Research, Vol. 23, pp. 105-134

Zand, D. E. (1972). Trust and Managerial Problem Solving Administrative Science Quarterly Vol. 17 Issue 2 pp. 229-239

Zand, D. E. (1997). The leadership triad: knowledge, trust and power New York : Oxford University Press

\section{Biography}

Heather Short (Heather.short@port.ac.uk) is a PhD student at the University of Portsmouth, investigating issues of trust in Technology Enhanced Learning (TEL) in the workplace, especially in SMEs. She has many years of experience of both the workplace and TEL, firstly with a multi-national technology company and then as an SME owner-manager. A paper based on her MBA dissertation investigating virtual learning in SMEs was shortlisted for the Alan Moon Memorial Prize at UFHRD (University Forum for HR Development) 2012. She co-chaired the Technology Enhanced Learning at Work stream at UFHRD 2013, where she also presented a paper on which this article is based. 